Article

\title{
Inhibitory Effect of Antidesma bunius Fruit Extract on Carbohydrate Digestive Enzymes Activity and Protein Glycation In Vitro
}

\author{
Pattamaporn Aksornchu ${ }^{1}$, Netima Chamnansilpa ${ }^{1}$, Sirichai Adisakwattana ${ }^{1}{ }^{(0)}$, Thavaree Thilavech ${ }^{2}$, \\ Charoonsri Choosak ${ }^{1}$, Marisa Marnpae ${ }^{1,3}$, Kittana Mäkynen ${ }^{1}{ }^{1}$, Winai Dahlan ${ }^{3}$ and Sathaporn Ngamukote ${ }^{1,3, *}$ \\ 1 Phytochemical and Functional Food Research Unit for Clinical Nutrition, Department of Nutrition and \\ Dietetics, Faculty of Allied Health Sciences, Chulalongkorn University, Bangkok 10330, Thailand; \\ paksornchu@gmail.com (P.A.); m.netti7@gmail.com (N.C.); sirichai.a@chula.ac.th (S.A.); \\ charoonsri.c@gmail.com (C.C.); mmarisa.hsc@gmail.com (M.M.); kittana.m@chula.ac.th (K.M.) \\ 2 Department of Food Chemistry, Faculty of Pharmacy, Mahidol University, Bangkok 10400, Thailand; \\ thavaree.thi@mahidol.ac.th \\ 3 The Halal Science Center, Chulalongkorn University, Bangkok 10330, Thailand; winai.hsc@gmail.com \\ * Correspondence: sathaporn.n@chula.ac.th; Tel.: +66-2218-1116
}

check for updates

Citation: Aksornchu, P.; Chamnansilpa, N.; Adisakwattana, S.; Thilavech, T.; Choosak, C.; Marnpae, M.; Mäkynen, K.; Dahlan, W.; Ngamukote, S. Inhibitory Effect of Antidesma bunius Fruit Extract on Carbohydrate Digestive Enzymes Activity and Protein Glycation In Vitro. Antioxidants 2021, 10, 32. https://doi.org/10.3390/antiox 10010032

Received: 2 December 2020 Accepted: 24 December 2020 Published: 30 December 2020

Publisher's Note: MDPI stays neutral with regard to jurisdictional clai$\mathrm{ms}$ in published maps and institutional affiliations.

Copyright: (C) 2020 by the authors. Licensee MDPI, Basel, Switzerland. This article is an open access article distributed under the terms and conditions of the Creative Commons Attribution (CC BY) license (https:// creativecommons.org/licenses/by/ $4.0 /)$.

\begin{abstract}
Antidesma bunius (L.) spreng (Mamao) is widely distributed in Northeastern Thailand. Antidesma bunius has been reported to contain anthocyanins, which possess antioxidant and antihypertensive actions. However, the antidiabetic and antiglycation activity of Antidesma bunius fruit extract has not yet been reported. In this study, we investigated the inhibitory activity of anthocyanin-enriched fraction of Antidesma bunius fruit extract (ABE) against pancreatic $\alpha$-amylase, intestinal $\alpha$-glucosidase (maltase and sucrase), protein glycation, as well as antioxidant activity. A liquid chromatography-tandem mass spectrometry (LC-MS/MS) chromatogram revealed that ABE contained phytochemical compounds such as cyanidin-3-glucoside, delphinidin-3-glucoside, ellagic acid, and myricetin-3-galactoside. ABE inhibited intestinal maltase and sucrase activity with the $\mathrm{IC}_{50}$ values of $0.76 \pm 0.02 \mathrm{mg} / \mathrm{mL}$ and $1.33 \pm 0.03 \mathrm{mg} / \mathrm{mL}$, respectively. Furthermore, $\mathrm{ABE}$ $(0.25 \mathrm{mg} / \mathrm{mL})$ reduced the formation of fluorescent AGEs and the level of $\mathrm{N}^{\varepsilon}$-carboxymethyllysine $\left(\mathrm{N}^{\varepsilon}-\mathrm{CML}\right)$ in fructose and glucose-induced protein glycation during four weeks of incubation. During the glycation process, the protein carbonyl and $\beta$-amyloid cross structure were decreased by $\mathrm{ABE}$ $(0.25 \mathrm{mg} / \mathrm{mL})$. In addition, ABE exhibited antioxidant activity through DPPH radical scavenging activity and Trolox equivalent antioxidant capacity (TEAC) with the $\mathrm{IC}_{50}$ values $15.84 \pm 0.06 \mu \mathrm{g} / \mathrm{mL}$ and $166.1 \pm 2.40 \mu \mathrm{g} / \mathrm{mL}$, respectively. Meanwhile, ferric reducing antioxidant power (FRAP) showed an $\mathrm{EC}_{50}$ value of $182.22 \pm 0.64 \mu \mathrm{g} / \mathrm{mL}$. The findings suggest that $\mathrm{ABE}$ may be a promising agent for inhibiting carbohydrate digestive enzyme activity, reducing monosaccharide-induced protein glycation, and antioxidant activity.
\end{abstract}

Keywords: $\alpha$-amylase; $\alpha$-glucosidase; Antidesma bunius; protein glycation; anthocyanins; antioxidant

\section{Introduction}

Diabetes is a group of abnormal carbohydrate, protein, and lipid metabolisms that contributes to chronically elevated blood glucose levels, known as hyperglycemia [1,2]. Long-term carbohydrate consumption, including the type and amount of dietary carbohydrate, is the leading risk factor for the induction of hyperglycemia, causing insulin resistance by acting on targeting cells such as adipose tissue and muscle cells [3-6]. After meal intake, starch is digested by pancreatic $\alpha$-amylase to produce oligosaccharides and disaccharides and further hydrolyzed by intestinal $\alpha$-glucosidase to yield absorbable monosaccharides [7,8]. Consequently, monosaccharides' absorption into the bloodstream occurs in the small intestine through glucose transporters, increasing postprandial blood 
glucose [1]. In diabetic patients, uncontrolled hyperglycemia leads to the onset and progression of diabetic vascular complications such as retinopathy, nephropathy, neuropathy, and cardiovascular diseases [9]. The important pathway involved in the pathogenesis of diabetic complications is the formation of advanced glycation endproducts (AGEs), resulting from non-enzymatic glycation between the carbonyl group of reducing sugar and the free amino group of protein [10]. The scientific evidence suggests that the binding of AGEs and receptors for AGEs (RAGEs) triggers the intracellular signaling involving the activation of reactive oxygen species (ROS) generation, inflammatory cytokine production, macrophage-platelet interaction, and thrombotic reaction, leading to vascular damage [11]. The overproduction of ROS during the glycation process results in the deterioration of biological molecules such as protein, lipid, and DNA, contributing to the pathogenesis of several diseases such as Alzheimer's diseases, cardiovascular disease, and cancer [9].

The previous study revealed that the inhibition of carbohydrate digestive enzymes could delay the monosaccharide absorption into the bloodstream, resulting in the decreased postprandial blood glucose concentration [12]. Moreover, achieving glycemic control or reducing hyperglycemia markedly decreases the level of glycated protein ( $\mathrm{HbA1c})$, an important risk indicator for long-term diabetic complications [13]. In clinical practice, acarbose, $\alpha$-glucosidase inhibitor, has been used to manage postprandial glucose level in diabetic patients $[14,15]$. However, aminoguanidine, a promising antiglycation agent, was terminated in clinical trials with serious side effects such as flu-like symptoms, anemia, vasculitis, myocardial infarction, congestive heart failure, and arterial fibrillation $[9,10,16]$.

Nowadays, the inhibition of carbohydrate digestion and the prevention of AGE formation has been of great interest to lower postprandial hyperglycemia and decrease protein glycation, especially in plant-derived products containing phytochemicals [17-19]. For example, anthocyanin-rich berries exhibited antioxidants, anti-glycation, antidiabetic, including pancreatic $\alpha$-amylase and intestinal $\alpha$-glucosidase inhibitions in in vitro studies [20,21]. Berries, including black raspberry, blueberry, blackberry, have also been reported to inhibit fructose-induced protein glycation and aggregation [22]. Moreover, the extract of Clitoria ternatea flower inhibited the formation of AGEs and prevented oxidative damage to bovine serum albumin (BSA) [23].

Antidesma bunius (L.) Spreng, Mamao, a berry of the family Euphorbiaceae, is locally cultivated and distributed in Northeastern Thailand. Interestingly, the extract of Antidesma bunius fruit contains polyphenols, including gallic acid, epicatechin, catechin, and cyanidin3-glucoside, which demonstrate antioxidant activity in various models [24]. It also exhibited antihypertensive activity by scavenging superoxide radicals, inhibiting the formation of lipid and protein oxidation, and increasing expression of eNOS in $\mathrm{N}^{\omega}$-nitro-L-arginine methyl ester-induced hypertensive rats [25]. In high fat diet-induced rats, the extract of Antidesma bunius fruit suppressed the gene expression of lipogenic enzymes and reduced the level of triglyceride and inflammation [26,27]. Although the extract of Antidesma bunius fruit shows various biological properties, its inhibitory effect against carbohydrate digestive enzymes and protein glycation remains unknown. Therefore, this study aimed to investigate the inhibitory activity of anthocyanin-enriched fraction of Antidesma bunius fruit extract (ABE) on pancreatic $\alpha$-amylase and intestinal $\alpha$-glucosidase. Moreover, this study also examined ABE's inhibitory effect on fructose/glucose-induced protein glycation, oxidative protein damage, and protein aggregation. Finally, the phytochemical composition and antioxidant activity of ABE was evaluated.

\section{Materials and Methods}

\subsection{Chemicals}

Folin-Cioclateu's phenol reagent, gallic acid, porcine pancreatic $\alpha$-amylase (Type VIB), rat intestinal acetone powder, 3,5-dinitrosalicylic acid, bovine serum albumin (BSA, fraction $\mathrm{V})$, aminoguanidine hydrochloride (AG), guanidine hydrochloride, thioflavin $\mathrm{T}$, 2,2-diphenyl-1-picrylhydrazyl (DPPH), 2,2'-Azino-bis(3-ethylbenzothiazoline-6-sulfonic acid) diammonium salt (ABTS), 6-hydroxy-2,5,7,8-tetramethylchromane-2-carboxylic acid 
(Trolox), and 2,4,6-tris(2-pyridyl)-s-triazine (TPTZ), delphinidin-3-glucoside (D3G) were purchased from Sigma-Aldrich Co. (St. Louis, MO, USA). 2,4-dinitrophenylhydrazine (DNPH), D-maltose, D-fructose, D-glucose, sucrose, and iron (II) sulfate were purchased from Ajax Finechem (Taren Point, Australia). Trichloroacetic acid (TCA) was purchased from Merck (Darmstadt, FR, Germany). A glucose liquid color kit was purchased from HUMAN Gesellschaft für Biochemica und Diagnostica mbH (Wiesbaden, Germany). Acarbose was purchased from Bayer AG Pharmaceutical (Berlin, Germany). Cyanidin-3-O-glucoside (C3G) was obtained from PhytoLab GmbH \& Co. KG (Vestenbergsgreuth, Germany). All other chemicals used in this study were analytical grade.

\subsection{Plant Materials}

The dark-purple color fruit (mature ripened stage) of Antidesma bunius was collected during August-September 2017 from Sakon Nakhon province, Northeastern Thailand. The plant was authenticated by a taxonomist Parinyanoot Klinratana at Professor Kasin Suvatabhandhu Herbarium, Department of Botany, Faculty of Science, Chulalongkorn University, Thailand. The voucher specimen was 015866 (BCU).

\subsection{Sample Preparation and Extraction}

The fruit extraction was performed according to a previous method with a slight modification [28]. The fruit (10 kg) was deseeded and blended with distilled water (20 L). The sample was filtered through a sieve cloth and centrifuged at $3500 \mathrm{rpm}$ for $5 \mathrm{~min}$ at $4{ }^{\circ} \mathrm{C}$. The solution was lyophilized using a freeze-dryer. The freeze-dried powder $(1 \mathrm{~g})$ was dissolved in distilled water $(20 \mathrm{~mL})$. The anthocyanin-rich fraction was purified using $\mathrm{C}_{18}$ solid-phase extraction (Strata-C18E, Phenomenex Inc., Torrance, CA, USA) preconditioned with $0.2 \%$ formic acid in acetonitrile $(6 \mathrm{~mL})$ and then pre-equilibrated with $0.2 \%$ formic acid in water $(6 \mathrm{~mL})$. Consequently, the sample $(6 \mathrm{~mL})$ was loaded into an extraction tube, washed with $0.2 \%$ formic acid in water $(6 \mathrm{~mL})$ and water $(12 \mathrm{~mL})$. After that, acetonitrile $(80 \% v / v$ in water) was used to elute the anthocyanin-rich fraction. This fraction was evaporated at $50{ }^{\circ} \mathrm{C}$ (BUCHI ROTAVAPOR, Flawil, Switzerland) to remove the solvent. The anthocyanin-rich Antidesma bunius fruit extract (ABE) was kept at $-20{ }^{\circ} \mathrm{C}$ until use. In the experiment, $\mathrm{ABE}$ was dissolved in distilled water.

\subsection{Determination of Total Phenolic and Anthocyanin Content}

The total phenolic content of $\mathrm{ABE}$ was determined using the Folin-Ciocalteau method [14]. In brief, $1 \mathrm{mg} / \mathrm{mL}$ ABE $(50 \mu \mathrm{L})$ was mixed with $50 \mu \mathrm{L}$ Folin-Ciocalteu reagent (10-fold dilution with distilled water) and $50 \mu \mathrm{L} \mathrm{Na}_{2} \mathrm{CO}_{3}(10 \% w / v)$. After 30 min of incubation in the dark, the absorbance was measured at $760 \mathrm{~nm}$. The phenolic content was expressed as mg gallic acid equivalent (GAE)/g extract.

The total anthocyanin content of $\mathrm{ABE}$ was measured by the $\mathrm{pH}$ differential method [29]. The extract $(1 \mathrm{mg} / \mathrm{mL} ; 250 \mu \mathrm{L})$ was mixed with $750 \mu \mathrm{L}$ of two different buffer systems, $0.025 \mathrm{M}$ potassium chloride $(\mathrm{pH} 1.0)$ and $0.4 \mathrm{M}$ sodium acetate $(\mathrm{pH} 4.5)$. All sample solutions were incubated at room temperature for $20 \mathrm{~min}$ in the dark and monitored the absorbance at a wavelength of $520 \mathrm{~nm}$ and $700 \mathrm{~nm}$. The absorbance of the solution was calculated by the following formula: $\mathrm{A}=(\mathrm{A} 520-\mathrm{A} 700) \mathrm{pH} 1.0-(\mathrm{A} 520-\mathrm{A} 700) \mathrm{pH} 4.5$. The anthocyanin content was obtained from

$$
\text { Anthocyanin content }(\mathrm{mg} / \mathrm{L})=\frac{\mathrm{A} \times \mathrm{MW} \times \mathrm{DF} \times 1000}{\varepsilon \times \lambda \times \mathrm{c}}
$$

where $\mathrm{A}$ is the absorbance of sample, MW is the molecular weight of cyanidin-3-glucoside (C3G), $\varepsilon$ is a molar extinction coefficient of $C 3 G$ as $26,900 \mathrm{~L} \cdot \mathrm{mol}^{-1} \mathrm{~cm}^{-1}, \lambda$ is the path length $(\mathrm{cm}), \mathrm{c}$ is the sample concentration $(\mathrm{mg} / \mathrm{L})$. Anthocyanin content was expressed as mg C3G equivalent/g extract. 


\subsection{Identification of Phytochemical Compounds}

The phytochemical compounds in ABE were characterized using liquid chromatographymass spectrometry (LC-MS/MS) according to a previously published method with a minor modification [30]. The HPLC system was equipped with a 6545 Quadrupole-time of flight (TOF) Mass spectrometer (Agilent Technologies, Santa Clara, CA, USA). The phenolic compounds were separated using the Luna $\mathrm{C}_{18}$ column $(150 \times 2.0 \mathrm{~mm}, 3 \mu \mathrm{m}$, Phenomenex Inc., Torrance, CA, USA). The mobile phase consisted of (A) water: formic acid: acetonitrile $(95: 2: 3 \mathrm{v} / \mathrm{v} / \mathrm{v})$; and $(\mathrm{B})$ water: formic acid: acetonitrile $(48: 2: 50 \mathrm{v} / \mathrm{v} / \mathrm{v})$. The flow rate was set at $0.20 \mathrm{~mL} / \mathrm{min}$. The gradient program was $5 \%$ (B), $25 \%$ (B) in $50 \mathrm{~min}$, and $5 \%$ (B) in $5 \mathrm{~min}$. The injection volume was $5 \mu \mathrm{L}$. The phenolic compounds were identified in negative and positive modes with a mass range of $m / z 100$ to 3000 . The mass spectrophotometer (MS) condition had the following parameters: nitrogen gas temperature at $325^{\circ} \mathrm{C}$, gas flow at $11 \mathrm{~L} / \mathrm{min}$, nebulizer gas at $35 \mathrm{psi}$, sheath gas temperature at $350{ }^{\circ} \mathrm{C}$, sheath gas flow at $11 \mathrm{~L} / \mathrm{min}$, capillary at $3500 \mathrm{~V}$, and fragmentor voltage at $125 \mathrm{~V}$. The interpretation of MS/MS data were carried out using Respect, GNPS, and MassBank mass spectral libraries. The identification score of $80 \%$ was selected for mass verification.

\subsection{Quantification of Individual Anthocyanin}

According to a previous method with modification, the individual anthocyanin in $\mathrm{ABE}$ was quantified using LC-MS/MS system [31,32]. The high-performance liquid chromatography (HPLC) system (Agilent 1290, Agilent Technologies, Santa Clara, CA, USA) consisted of a binary pump and autosampler with a reverse-phase C-18 Inertsil ODS-2 column $\left(250 \times 4.6 \mathrm{~mm}, 5 \mu \mathrm{m}, 150 \mathrm{~A}^{\circ}\right.$, Techno Quartz Inc., Tokyo, Japan). The mobile phase was formic acid: water (10:90 v/v; mobile phase A) and formic acid: water: acetonitrile: methanol (10:40:22.5:22.5 v/v/v/v; mobile phase B). The anthocyanin was separated by a linear gradient following: 15-20\% (B) in $5 \mathrm{~min}, 20-27 \%$ (B) in $35 \mathrm{~min}, 27-65 \%$ (B) in $45 \mathrm{~min}$, $65-100 \%$ (B) in $50 \mathrm{~min}$ and then back to $15 \%$ (B) until $60 \mathrm{~min}$ at a flow rate of $0.6 \mathrm{~mL} / \mathrm{min}$. The injection volume of the sample was $5 \mu \mathrm{L}$. The anthocyanin was quantified using a mass spectrophotometer with electrospray ionization (ABSciex QTRAP 5500, Sciex, Framingham, MA, USA). The anthocyanin content was determined by the multiple reaction monitoringenhanced product ion mode (MRM-EPI) under condition was set as follows: ion spray voltage $5.5 \mathrm{kV}$, source temperature $500^{\circ} \mathrm{C}$, curtain gas $25 \mathrm{psi}$, collision energy $20 \mathrm{eV}$. Data were analyzed using "ABSciex analyst" software (Sciex, Framingham, MA, USA). Anthocyanins standard was cyanidin-3-glucoside (C3G) and delphinidin-3-glucoside (D3G).

\subsection{The Inhibition of Carbohydrate Digestive Enzymes}

The inhibition of pancreatic $\alpha$-amylase was performed according to a previous report [14]. In brief, the ABE at a concentration of $15-60 \mathrm{mg} / \mathrm{mL}(20 \mu \mathrm{L})$ and $4 \mathrm{~g} / 1$ starch solution $(75 \mu \mathrm{L})$ were mixed in a $0.1 \mathrm{M}$ phosphate buffer, $\mathrm{pH} 6.9(130 \mu \mathrm{L})$. After the addition of $75 \mu \mathrm{L}$ pancreatic $\alpha$-amylase (three units $/ \mathrm{mL}$ ), the mixture was incubated at $37^{\circ} \mathrm{C}$ for $10 \mathrm{~min}$. Then, $1 \%$ dinitrosalicylic acid $(250 \mu \mathrm{L})$ was added to the mixture and heated for $10 \mathrm{~min}$ to stop the enzyme activity. The mixture was incubated with $40 \%$ potassium sodium tartrate $(250 \mu \mathrm{L})$ and kept at room temperature. The absorbance was monitored at $540 \mathrm{~nm}$. In this study, acarbose was used as a positive control. The inhibitory activity was expressed as a percentage of inhibition.

$$
\% \text { inhibition }=\left[\frac{\mathrm{Abs}_{\text {control }}-\mathrm{Abs}_{\text {sample }}}{\mathrm{Abs}_{\mathrm{control}}}\right] \times 100
$$

$\mathrm{Abs}_{\text {control }}$ was absorbance without $\mathrm{ABE}$ or acarbose, and $\mathrm{Abs}_{\text {sample was the absorbance }}$ of $\mathrm{ABE}$ or acarbose.

The inhibition of intestinal $\alpha$-glucosidase was determined following a previously published method [14]. The rat intestinal acetone powder was dissolved in $0.9 \% \mathrm{NaCl}$ solution at a concentration of $100 \mathrm{mg} / 3 \mathrm{~mL}$ and centrifuged at $12,000 \times \mathrm{g}$ for $30 \mathrm{~min}$ at $4{ }^{\circ} \mathrm{C}$. The supernatant was collected for further analysis. In the assay of maltase and sucrase 
activity, ABE $(10 \mu \mathrm{L})$ was mixed with $86 \mathrm{mM}$ maltose $(30 \mu \mathrm{L})$ or $400 \mathrm{mM}$ sucrose $(40 \mu \mathrm{L})$ in $0.1 \mathrm{M}$ phosphate buffer, $\mathrm{pH} 6.9$, respectively. The reaction was incubated at $37^{\circ} \mathrm{C}$ for $30 \mathrm{~min}$ (maltase assay) or $60 \mathrm{~min}$ (sucrase assay). Then, the reaction was heated at $100{ }^{\circ} \mathrm{C}$ for $10 \mathrm{~min}$. The release of glucose was determined by the glucose oxidase method. The absorbance was measured at $500 \mathrm{~nm}$. In this study, acarbose $(0.16-5 \mu \mathrm{g} / \mathrm{mL})$ was used as a positive control. The results were expressed as the half-maximal inhibitory concentration $\left(\mathrm{IC}_{50}\right)$ values (the concentration required to the percentage of inhibition, with $50 \%$ of the enzyme activity) that were calculated using the curve of logarithmic regression.

\subsection{Protein Glycation}

The protein glycation assay was performed following a published method [33]. Briefly, $700 \mu \mathrm{L}$ of BSA (10 mg/mL final concentration) was mixed with $560 \mu \mathrm{L}$ of fructose or glucose (0.5 M final concentration) in $0.1 \mathrm{M}$ phosphate buffer saline (PBS, pH 7.4) containing $0.02 \%$ sodium azide. The solution was mixed with $140 \mu \mathrm{L}$ of ABE in $0.1 \mathrm{M}$ PBS $(0.025-0.25 \mathrm{mg} / \mathrm{mL}$ final concentration) or aminoguanidine $(0.25 \mathrm{mg} / \mathrm{mL}$ final concentration). The solution was incubated at $37^{\circ} \mathrm{C}$ in the dark for four weeks. The fluorescent intensity of AGE formation was measured weekly using a spectrofluorometer (Fluoroskan Ascent, Thermo Fisher Scientific, Vantaa, Finland) at excitation and emission wavelength $355 \mathrm{~nm}$ and $460 \mathrm{~nm}$, respectively. The following equation calculated the percentage inhibition

$$
\text { Inhibition of fluorescent AGEs }(\%)=\left(\left(F_{C}-F_{C B}\right)-\left(F_{S}-F_{S B}\right) /\left(F_{C}-F_{C B}\right)\right) \times 100
$$

where $\mathrm{F}_{\mathrm{C}}$ and $\mathrm{F}_{\mathrm{CB}}$ were the fluorescent intensity of control with monosaccharide and blank of control without monosaccharide. $F_{S}$ and $F_{S B}$ were the fluorescent intensity of the sample with monosaccharide and blank of the sample without monosaccharide.

The level of $\mathrm{N}^{\mathcal{E}}$-carboxymethyllysine $\left(\mathrm{N}^{\mathcal{E}}\right.$-CML), a non-fluorescent AGEs, was analyzed by enzyme-linked immunosorbent assay (ELISA) kit following the manufacturer's protocol (Cyclex Co., Ltd., Nagano, Japan). The absorbance was measured at $450 \mathrm{~nm}$. The level of $\mathrm{N}^{\varepsilon}-\mathrm{CML}$ was calculated by the CML-human serum albumin (HSA) standard curve.

\subsection{Determination of Protein Carbonyl Content}

The content of protein carbonyl was determined using a 2,4-dinitrophenylhydrazine (DNPH) assay according to a previous report [33]. Briefly, the glycated BSA $(100 \mu \mathrm{L})$ was mixed with $10 \mathrm{mM}$ DNPH in $2.5 \mathrm{M} \mathrm{HCl}(400 \mu \mathrm{L})$ and incubated for $60 \mathrm{~min}$ in the dark. After incubation, the protein was precipitated by $20 \%(w / v)$ trichloroacetic acid $(500 \mu \mathrm{L})$, kept on ice for $5 \mathrm{~min}$, and centrifuged at $10,000 \times \mathrm{g}$ for $10 \mathrm{~min}$ at $4{ }^{\circ} \mathrm{C}$. The protein pellet was washed with methanol: ethyl acetate $(1: 1 v / v)$ three times and dissolved in $250 \mu \mathrm{L}$ $6 \mathrm{M}$ guanidine hydrochloride. The absorbance was read at $370 \mathrm{~nm}$. The carbonyl content was calculated using the molar extinction coefficient of 22,000 (DNPH). The results were expressed as nmol carbonyl/mg protein.

\subsection{Determination of Protein Aggregation}

The level of $\beta$-amyloid cross structure was analyzed by thioflavin $\mathrm{T}$, according to a previous study [33]. The glycated BSA $(50 \mu \mathrm{L})$ was mixed with $64 \mu \mathrm{M}$ thioflavin $\mathrm{T}(50 \mu \mathrm{L})$ in 0.1 M PBS, pH 7.4. The mixture was incubated at room temperature for $60 \mathrm{~min}$. The $\beta$-amyloid cross structure level was measured using a spectrofluorometer at excitation and emission wavelength with $435 \mathrm{~nm}$ and $485 \mathrm{~nm}$, respectively.

\subsection{2,2-Diphenyl-1-picrylhydrazyl (DPPH) Scavenging Activity}

2,2-Diphenyl-1-picrylhydrazyl (DPPH) radical scavenging activity was determined following the previous protocol [34]. In brief, $100 \mu \mathrm{L}$ of ABE (10-60 $\mu \mathrm{g} / \mathrm{mL})$ was mixed with $100 \mu \mathrm{L}$ of $0.2 \mathrm{mM}$ DPPH in ethanol and incubated for $30 \mathrm{~min}$ at room temperature. The absorbance was measured at $515 \mathrm{~nm}$. Ascorbic acid $(5-30 \mu \mathrm{g} / \mathrm{mL})$ was used as a positive control. The $\mathrm{IC}_{50}$ value was calculated using the curve of the percentage of DPPH scavenging activity corresponding to the various sample concentrations. 


\subsection{Trolox Equivalent Antioxidant Capacity (TEAC)}

Trolox Equivalent Antioxidant Capacity (TEAC) was analyzed according to a previously published method [35]. In brief, $2.45 \mathrm{mM}$ potassium sulfate was mixed with $7 \mathrm{mM}$ ABTS at a ratio of $1: 1$ and incubated at room temperature for at least $16 \mathrm{~h}$ in the dark to generate $\mathrm{ABTS}^{+}$radicals. After incubation, the $\mathrm{ABTS}^{+}$solution was diluted with $0.1 \mathrm{M}$ PBS, pH 7.4, to obtain the absorbance at $0.9-1.0$ before analysis. ABE, at a concentration of $0.02-2 \mathrm{mg} / \mathrm{mL}\left(20 \mu \mathrm{L}\right.$, ) was incubated with $180 \mu \mathrm{L} \mathrm{ABTS}{ }^{+}$solution and incubated at room temperature for $6 \mathrm{~min}$. Trolox $(0.06-1 \mathrm{mg} / \mathrm{mL})$ was used as a positive control. The absorbance was measured at $734 \mathrm{~nm}$. The $\mathrm{IC}_{50}$ value was calculated using the curve of the percentage of $\mathrm{ABTS}^{+}$scavenging activity corresponding to the various sample concentrations.

\subsection{Ferric Reducing Antioxidant Power (FRAP)}

The Ferric Reducing Antioxidant Power (FRAP) value was determined according to a previous study [24]. The FRAP reagent was prepared by mixing $10 \mathrm{mM}$ 2,4,6-Tris(2-pyridyl)s-triazine (TPTZ) in $40 \mathrm{mM} \mathrm{HCl}$ with $20 \mathrm{mM} \mathrm{FeCl}_{3}$ and $300 \mathrm{mM}$ acetate buffer (1:1:10 v/v/v). The FRAP reagent was incubated at $37^{\circ} \mathrm{C}$ before analysis. The $\mathrm{ABE}$ at a concentration of $0.02-1 \mathrm{mg} / \mathrm{mL}(20 \mu \mathrm{L})$ was mixed with $180 \mu \mathrm{L}$ of FRAP reagent and incubated at $37^{\circ} \mathrm{C}$ for $30 \mathrm{~min}$ in the dark. The absorbance was measured at $595 \mathrm{~nm}$. Ascorbic acid $(0.01-1 \mathrm{mg} / \mathrm{mL})$ was used as a positive control. The $\mathrm{EC}_{50}$ value was calculated using the curve of the percentage of ferric reducing antioxidant capacity corresponding with the various concentration of samples.

\subsection{Statistical Analysis}

All experiments were performed in triplicate $(n=3)$. The values are presented as means \pm standard error of the mean (SEM). Data were analyzed using one-way analysis of variance (ANOVA), followed by Duncan's post hoc test (SPSS version 17, SPSS Inc., Chicago, IL, USA). $p<0.05$ was considered statistically significant.

\section{Results}

\subsection{Total Phenolic and Anthocyanin Content}

The total phenolic content of ABE was $300.9 \pm 1.6 \mathrm{mg}$ GAE/g extract, whereas the total anthocyanin content was $66.9 \pm 1.3 \mathrm{mg}$ cyanidin-3-glucoside/g extract.

\subsection{LC-MS/MS Identification and Characterization of Phytochemical Compounds in ABE}

The MS/MS spectral data of the phenolic composition of $A B E$ in negative and positive modes are presented in Figure 1. The characteristics of ABE phenolic compounds were identified by comparing their retention time and mass spectral data of product ions with the online database (Table 1). As shown in Table 1, the proposed phytochemical compounds in ABE was quinic acid, gallic acid, 6-galloylglucose, 2,5-dihydroxybenzoic acid, ellagic acid, myricetin-3-galactoside, quercetin-3-O-arabinoside, quercetin-3-galactoside, kaempferol-3rhamnoside, kaempferol-3-glucoside, delphinidin-3-glucoside, cyanidin-3-sambubioside, and cyanidin-3-glucoside.

\subsection{Quantification of Individual Anthocyanins in $A B E$}

The base peak and MS/MS fraction ion chromatogram of individual anthocyanins was obtained from LC-MS/MS analysis. D3G and C3G in ABE (Figure 2b) were characterized by comparing the retention time and mass spectral data of product ions with the standard (Figure 2a). D3G and C3G contents were quantified by comparing the calibration curve (Figure 3). The content of D3G and C3G in ABE was $21.7 \pm 0.8 \mathrm{mg} / \mathrm{g}$ extract and $31.4 \pm 1.4 \mathrm{mg} / \mathrm{g}$ extract, respectively. 


\subsection{The Inhibitory Effect of $A B E$ on Carbohydrate Digestive Enzymes}

The results showed that $\mathrm{ABE}(0.16-2.5 \mathrm{mg} / \mathrm{mL})$ inhibited intestinal maltase (5.5-91.8\%). Meanwhile, $\mathrm{ABE}(0.3-5 \mathrm{mg} / \mathrm{mL})$ exhibited inhibitory activity against intestinal sucrase (6.5-97\%). The $\mathrm{IC}_{50}$ values of $\mathrm{ABE}$ for intestinal maltase and sucrase were $0.76 \pm 0.02 \mathrm{mg} / \mathrm{mL}$ and $1.33 \pm 0.03 \mathrm{mg} / \mathrm{mL}$, respectively (Table 2), indicating that $\mathrm{ABE}$ had greater inhibitory activity on maltase than sucrase. Moreover, acarbose $(0.2-5 \mu \mathrm{g} / \mathrm{mL})$ inhibited intestinal maltase by $21.2-75.8 \%$, whereas at higher levels $(1.6-50 \mu \mathrm{g} / \mathrm{mL})$, it markedly inhibited intestinal sucrase by $16-85.1 \%$. In addition, the $\mathrm{IC}_{50}$ values of acarbose against maltase and sucrase were $0.89 \pm 0.07 \mu \mathrm{g} / \mathrm{mL}$ and $8.48 \pm 0.07 \mu \mathrm{g} / \mathrm{mL}$, respectively. The obtained results indicate that $\mathrm{ABE}$ has less potent than acarbose on the inhibition of carbohydrate digestive enzymes. In contrast, $\mathrm{ABE}(1-4 \mathrm{mg} / \mathrm{mL})$ slightly inhibited the activity of pancreatic $\alpha$-amylase by $11.2-34.1 \%$, and the $\mathrm{IC}_{50}$ value was $>4 \mathrm{mg} / \mathrm{mL}$. Meanwhile, the $\mathrm{IC}_{50}$ value of acarbose was $34.62 \pm 0.68 \mu \mathrm{g} / \mathrm{mL}$.

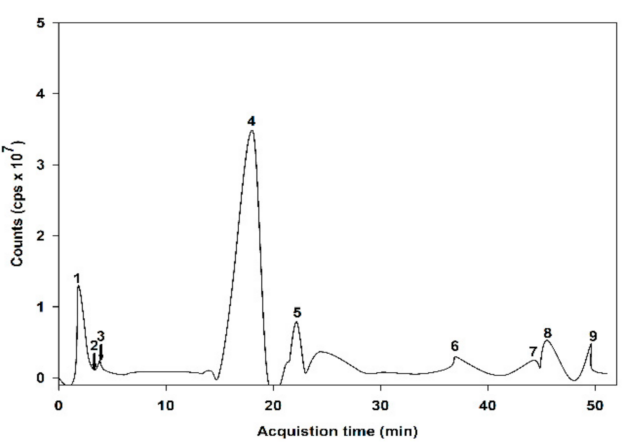

(A)

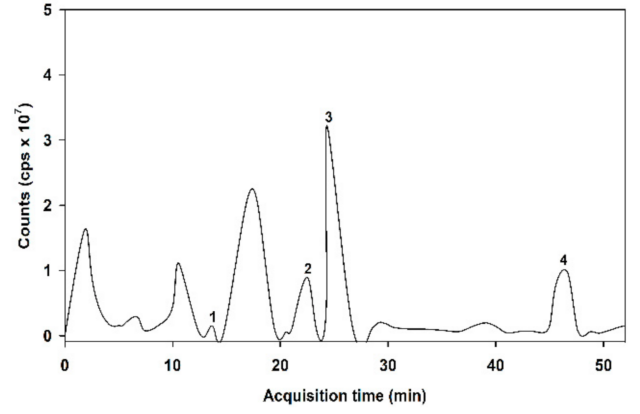

(B)

Figure 1. liquid chromatography-mass spectrometry (LC-MS/MS) chromatogram of the proposed phenolic compound of anthocyanin-rich fraction in Antidesma bunius fruit extract (ABE): (A) negative of ionization mode; (B) positive of ionization mode.

Table 1. Chromatographic mass spectrometry (MS) and MS/MS data of proposed phenolic compounds in an anthocyaninrich fraction of Antidesma bunius fruit extract (ABE).

\begin{tabular}{|c|c|c|c|}
\hline Peak No. & Rt (min) & Proposed Compounds & Product Ion \\
\hline \multicolumn{4}{|c|}{ Phenolic acids } \\
\hline 1 & 1.743 & Quinic acid & $192.0639(\mathrm{M}-\mathrm{H})^{-}$, Calcd Mass: 191.0567 \\
\hline 2 & 3.228 & Gallic acid & $170.0217(\mathrm{M}-\mathrm{H})^{-}$, Calcd Mass 169.0144 \\
\hline 3 & 4.076 & 6-Galloylglucose & $332.0743(\mathrm{M}-\mathrm{H})^{-}$, Calcd Mass: 331.0671 \\
\hline 4 & 21.945 & 2,5-dihydroxybenzoic acid & 154.0266 $(\mathrm{M}-\mathrm{H})^{-}$, Calcd Mass: 153.0194 \\
\hline 5 & 45.200 & Ellagic acid & $302.0063(\mathrm{M}-\mathrm{H})^{-}$, Calcd Mass: 300.999 \\
\hline \multicolumn{4}{|c|}{ Flavonols } \\
\hline 6 & 18.244 & Quercetin-3-O-arabinoglucoside & $596.1379(\mathrm{M}-\mathrm{H})^{-}$, Calcd Mass: 595.1308, MS/MS: 300.0274 \\
\hline 7 & 36.954 & Quercetin-3-galactoside & 464.0953 $(\mathrm{M}-\mathrm{H})^{-}$, Calcd Mass: 463.0883, MS/MS: 301.0345 \\
\hline 8 & 44.893 & Kaempferol -3-rhamnoside & 432.1052 (M - H $)^{-}$, Calcd Mass:431.098, MS/MS: 283.0605 \\
\hline 9 & 49.541 & Kaempferol-3-glucoside & 448.1006 $(\mathrm{M}-\mathrm{H})^{-}$, Calcd Mass: 447.0936, MS/MS: 285.4000 \\
\hline 10 & 13.427 & Myricetin-3-galactoside & $480.1576(\mathrm{M}-\mathrm{H})^{+}$, Calcd Mass: $481.1652, \mathrm{MS} / \mathrm{MS}: 319.1124$ \\
\hline \multicolumn{4}{|c|}{ Anthocyanins } \\
\hline 11 & 22.484 & Delphinidin-3-glucoside & 465.1811 (M) ${ }^{+}$, Calcd Mss: 465.1715, MS/MS: 303.1166 \\
\hline 12 & 24.200 & Cyanidin-3-sambubioside & $581.138(\mathrm{M})^{+}$, Calcd Mass: 581.1431, MS/MS: 287.0523 \\
\hline 13 & 46.069 & Cyanidin-3-glucoside & 448.1714 $(\mathrm{M}-\mathrm{H})^{+}$, Calcd Mass: 449.1802, MS/MS: 287.1236 \\
\hline
\end{tabular}




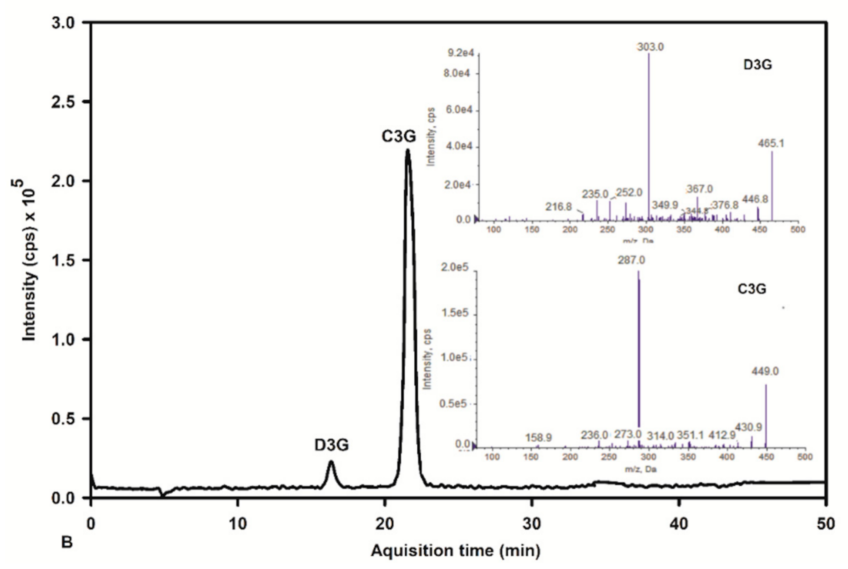

(A)

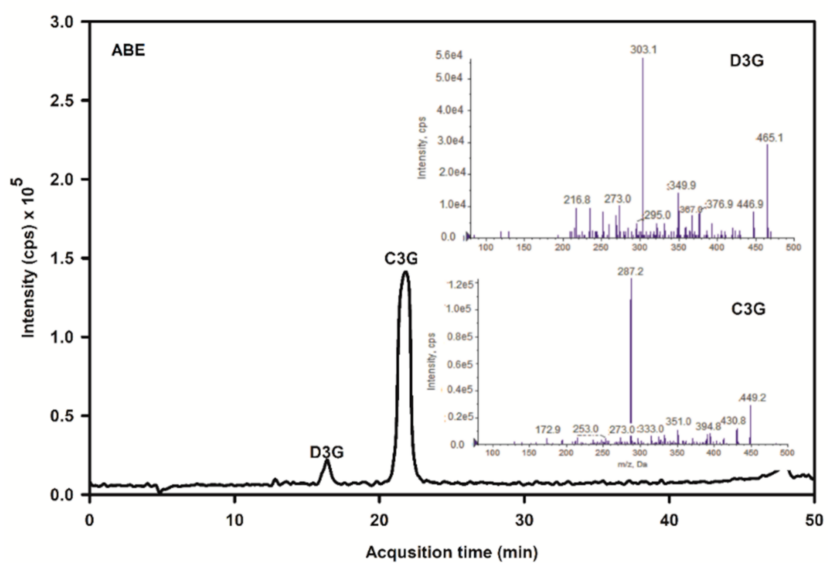

(B)

Figure 2. LC-MS/MS chromatogram of delphinidin-3-glucoside and cyanidin-3-glucoside of the anthocyanin-rich fraction of Antidesma bunius extract (ABE) with multiple reaction monitoringenhanced product ion mode (MRM-EPI): (A) chromatogram of anthocyanins standard; D3G: delphinidin-3-glucoside and peak and C3G: cyanidin-3-glucoside; (B) chromatogram of ABE; D3G: delphinidin-3-glucoside and C3G: cyanidin-3-glucoside.

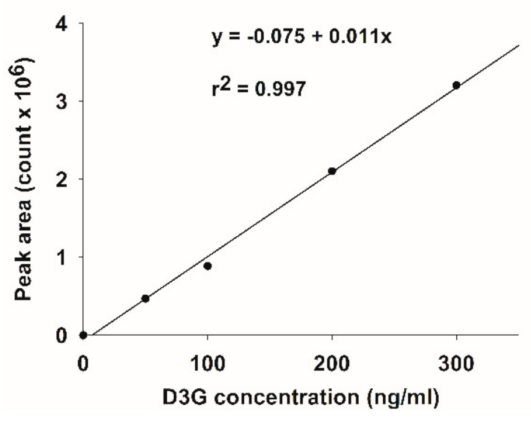

(A)

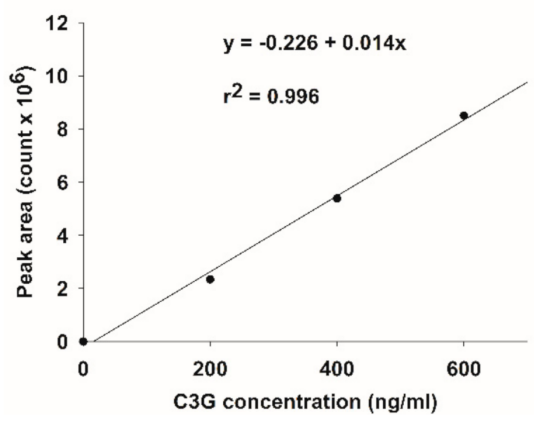

(B)

Figure 3. Calibration curve of anthocyanins: (A) delphinidin-3-glucoside (D3G); (B) cyanidin-3glucoside (C3G). 
Table 2. The inhibitory activity of anthocyanin-rich fraction of Antidesma bunius fruit extract (ABE) on carbohydrate digestive enzymes.

\begin{tabular}{cccc}
\hline \multirow{2}{*}{ Compounds } & \multicolumn{3}{c}{ IC $_{\mathbf{5 0}}$ Values } \\
\cline { 2 - 4 } & $\alpha$-Amylase & Maltase & Sucrase \\
\hline ABE $(\mathbf{m g} / \mathrm{mL})$ & $>4$ & $0.76 \pm 0.02$ & $1.33 \pm 0.03$ \\
Acarbose $(\mu \mathrm{g} / \mathrm{mL})$ & $34.62 \pm 0.68$ & $0.89 \pm 0.07$ & $8.48 \pm 0.07$ \\
\hline
\end{tabular}

The results are expressed as mean $\pm \operatorname{SEM}(n=3)$. $\mathrm{IC}_{50}$ : Half-maximal inhibitory concentration.

\subsection{The Inhibitory Activity on Protein Glycation}

As shown in Figure 4, the formation of fluorescence AGEs in fructose and glucoseglycated BSA was 45.4-fold and 20.5-fold greater than that of BSA alone after four weeks of incubation (Figure $4 \mathrm{~A}, \mathrm{~B})$. In the fructose model, $\mathrm{ABE}(0.25 \mathrm{mg} / \mathrm{mL})$ reduced the formation of AGEs, ranging from 48.9-58\% throughout the four weeks of incubation. In the glucose model, the formation of AGEs was decreased by ABE $0.25 \mathrm{mg} / \mathrm{mL}$; about 25.3-34.5\%. At the same concentration, aminoguanidine $(0.25 \mathrm{mg} / \mathrm{mL})$ inhibited the formation of fluorescent AGEs in the fructose-glycated BSA (47.3\%) and glucose-glycated BSA (52.6\%). Our findings indicate that $\mathrm{ABE}(0.25 \mathrm{mg} / \mathrm{mL})$ exhibits a similar potent as aminoguanidine $(0.25 \mathrm{mg} / \mathrm{mL})$ to inhibit fructose-induced BSA glycation.

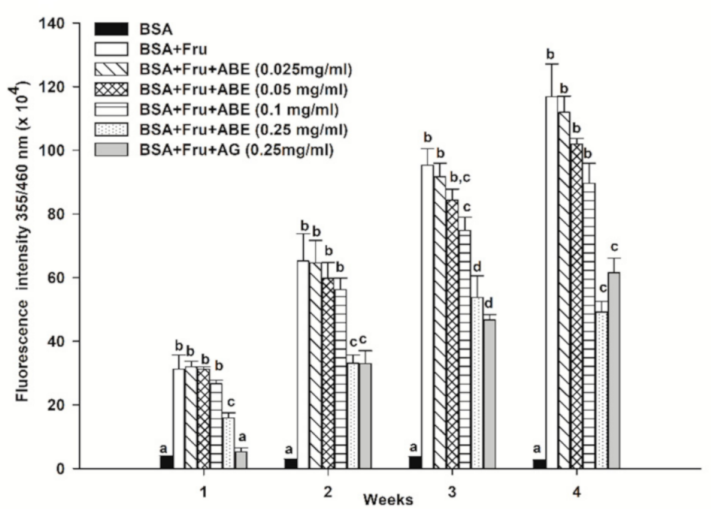

(A)

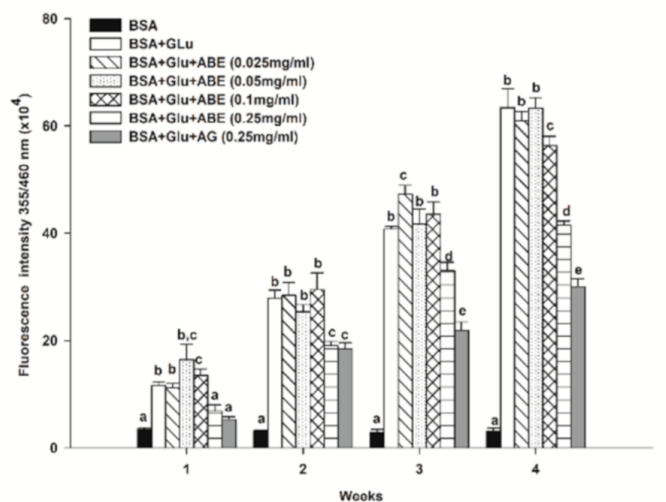

(B)

Figure 4. The effect of anthocyanin-rich fraction Antidesma bunius fruit extract (ABE, $0.025-0.25 \mathrm{mg} / \mathrm{mL}$ ) and aminoguanidine $(\mathrm{AG}, 0.25 \mathrm{mg} / \mathrm{mL}$ ) on the fluorescent AGE formation in bovine serum albumin (BSA) incubated with (A) 0.5 M fructose (Fru); (B) 0.5 M glucose (Glu) during 4 weeks of study. The results are expressed as mean $\pm \operatorname{SEM}(n=3)$. Results were statistically analyzed by one-way analysis of variance (ANOVA), following Duncan's multiple range test. The different letters in the same week indicate a significant difference at $p<0.05$. 
The formation of $\mathrm{N}^{\varepsilon}$-CML in both BSA-fructose and BSA-glucose systems is shown in Figure 5. In the fructose and glucose model, the $\mathrm{N}^{\varepsilon}$-CML level was 6.6-fold and 1.4-fold higher than that of BSA alone at week four. Furthermore, the addition of ABE $(0.25 \mathrm{mg} / \mathrm{mL})$ and aminoguanidine $(0.25 \mathrm{mg} / \mathrm{mL})$ decreased the level of $\mathrm{N}^{\varepsilon}-\mathrm{CML}$ in fructose-glycated BSA by $35.0 \%$ and $28.2 \%$, respectively. Whereas ABE $(0.25 \mathrm{mg} / \mathrm{mL})$ and aminoguanidine $(0.25 \mathrm{mg} / \mathrm{mL})$ inhibited the $\mathrm{N}^{\varepsilon}-\mathrm{CML}$ formation in glucose-glycated BSA by $26.2 \%$ and $35.5 \%$, respectively. These findings indicate that the inhibitory effect of $A B E(0.25 \mathrm{mg} / \mathrm{mL})$ on $\mathrm{N}^{\varepsilon}-\mathrm{CML}$ level had a similar potency with aminoguanidine $(0.25 \mathrm{mg} / \mathrm{mL})$ in fructose and glucose models.

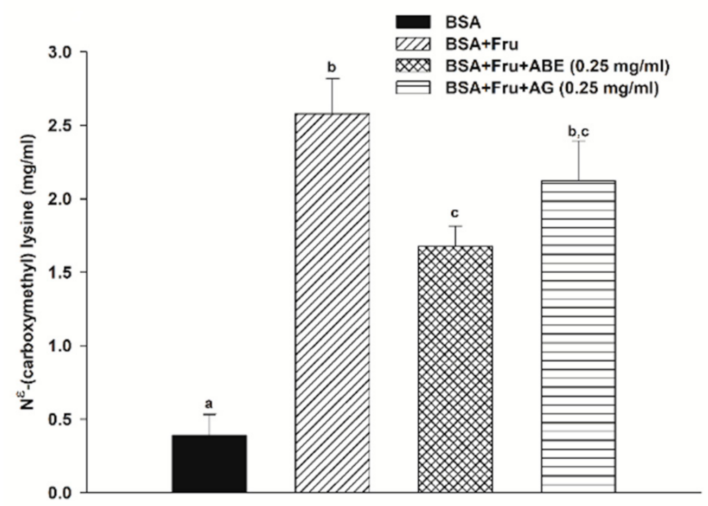

(A)

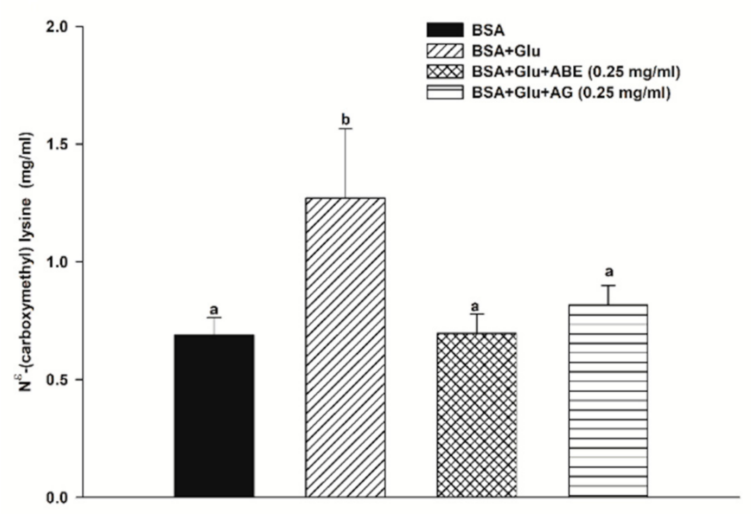

(B)

Figure 5. The effect of anthocyanin-rich fraction Antidesma bunius fruit extract (ABE, $0.25 \mathrm{mg} / \mathrm{mL}$ ) and aminoguanidine $\left(\mathrm{AG}, 0.25 \mathrm{mg} / \mathrm{mL}\right.$ ) on the $\mathrm{N}^{\varepsilon}$-(carboxymethyl) lysine $\left(\mathrm{N}^{\varepsilon}\right.$-CML) level in bovine serum albumin (BSA) incubated with (A) $0.5 \mathrm{M}$ fructose (Fru); (B) $0.5 \mathrm{M}$ glucose (Glu) during 4 weeks of study. The results are expressed as mean \pm SEM $(n=3)$. Results were statistically analyzed by one-way analysis of variance (ANOVA), following Duncan's multiple range test. The different letters indicate Scheme 0.

\subsection{The Inhibitory Effect of ABE on Protein Oxidation}

The protein carbonyl contents of fructose-glycated BSA are presented in Figure 6a. Our findings revealed that fructose increased the carbonyl contents by 4.9-fold to 11.8fold as compared to non-glycated BSA during four weeks of incubation. The carbonyl content of fructose-glycated BSA was reduced by ABE $(0.25 \mathrm{mg} / \mathrm{mL})(24.8-38.8 \%)$ at weeks two and four, respectively. Moreover, $\mathrm{ABE}$ at $0.1 \mathrm{mg} / \mathrm{mL}$ decreased the carbonyl content of fructose-glycated BSA $(32.2 \%)$ at week four. Whereas aminoguanidine $(0.25 \mathrm{mg} / \mathrm{mL})$ reduced the carbonyl content of fructose-glycated BSA by $34.4 \%$ (Figure 5a). As shown 
in Figure $6 \mathrm{~b}$, the glucose-mediated BSA glycation induced the carbonyl content higher than BSA throughout the four-week experiment (3.5-fold to 9.9-fold). The addition of ABE $(0.1-0.25 \mathrm{mg} / \mathrm{mL})$ significantly decreased the carbonyl content of glycated BSA at week three (15.5-26.7\%) and week four (11.8-17.5\%). Moreover, aminoguanidine $(0.25 \mathrm{mg} / \mathrm{mL})$ reduced glycated-glucose BSA's carbonyl content by $29.6 \%$ (Figure $6 \mathrm{~b}$ ) at week four of incubation. These results indicate that ABE had a similar potency as aminoguanidine to decrease carbonyl content in fructose-glycated BSA. However, the ABE was less potent than aminoguanidine on reducing protein carbonyl content in BSA incubated with glucose.

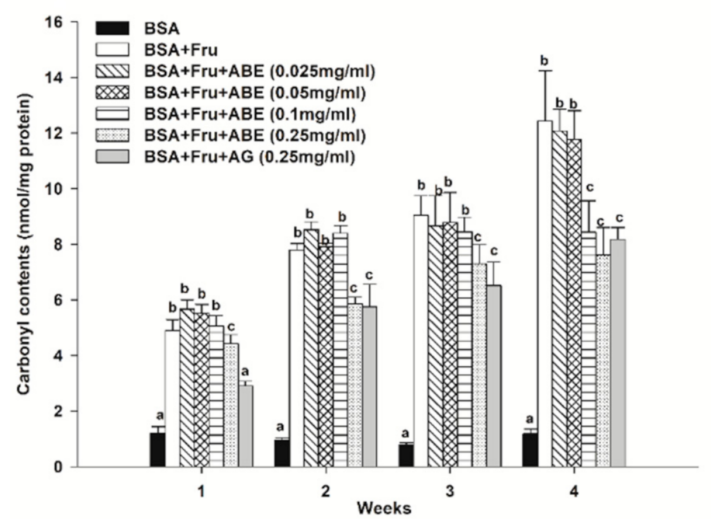

(A)

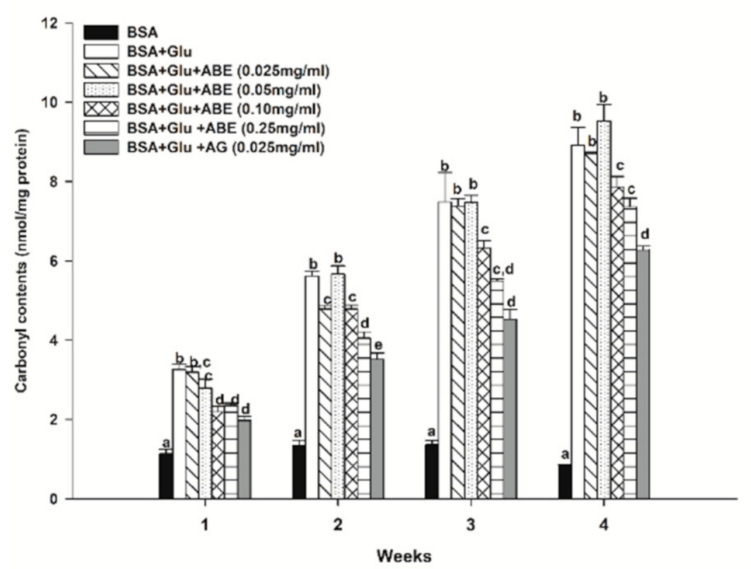

(B)

Figure 6. The effect of anthocyanin-rich fraction Antidesma bunius fruit extract (ABE, $0.025-0.25 \mathrm{mg} / \mathrm{mL}$ ) and aminoguanidine (AG, $0.25 \mathrm{mg} / \mathrm{mL}$ ) on the level of protein carbonyl content in bovine serum albumin (BSA) incubated with (A) $0.5 \mathrm{M}$ fructose (Fru); (B) $0.5 \mathrm{M}$ glucose (Glu) during the four weeks of study. The results are expressed as mean $\pm \operatorname{SEM}(n=3)$. Results were statistically analyzed by one-way analysis of variance (ANOVA), following Duncan's multiple range test. The different letters in the same week indicate a significant difference at $p<0.05$.

\subsection{The Inhibitory Effect of ABE on Protein Aggregation}

At four weeks of the experimental period, the formation of $\beta$-amyloid cross structure, a marker of protein aggregation, was found to increase in glycated BSA induced by fructose (1.7-fold) and glucose (1.0-fold) when compared to BSA alone (Figure 7). Interestingly, $\mathrm{ABE}$ at a concentration of $0.25 \mathrm{mg} / \mathrm{mL}$ decreased the formation of $\beta$-amyloid in fructoseand glucose-glycated BSA (Figure 7A,B) about $38.5 \%$ and $17.9 \%$, respectively. Similarly, the addition of aminoguanidine $(0.25 \mathrm{mg} / \mathrm{mL})$ caused a decrease in the formation of $\beta$ amyloid cross structure in glycated BSA induced by fructose $(23.1 \%)$ and glucose $(4.3 \%)$. 
According to these results, $\mathrm{ABE}$ was greater potent than aminoguanidine on the reduction of $\beta$-amyloid cross structure in glycated BSA.

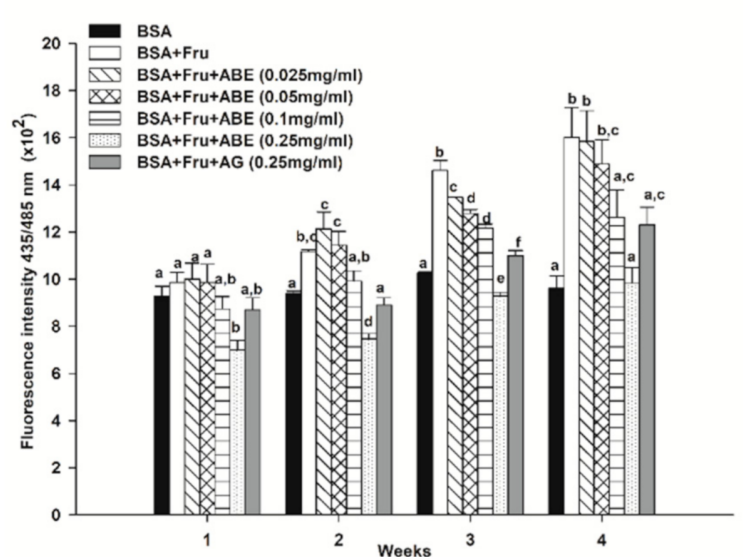

(A)

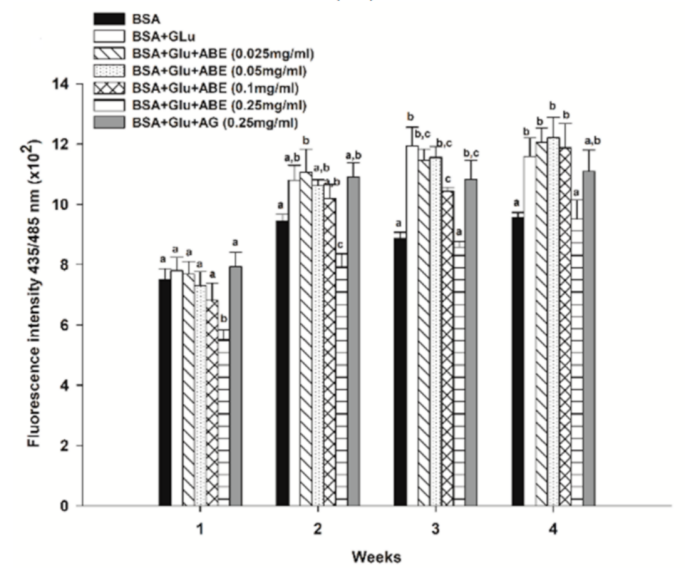

(B)

Figure 7. The effect of anthocyanin-rich fraction Antidesma bunius fruit extract (ABE, $0.025-0.25 \mathrm{mg} / \mathrm{mL}$ ) and aminoguanidine (AG, $0.25 \mathrm{mg} / \mathrm{mL}$ ) on the level of $\beta$-amyloid cross structure in bovine serum albumin (BSA) incubated with (A) 0.5 M fructose (Fru); (B) 0.5 M glucose (Glu) during the four weeks of study. The results are expressed as mean $\pm \operatorname{SEM}(n=3)$. Results were statistically analyzed by one-way analysis of variance (ANOVA), following Duncan's multiple range test. The different letters in the same week indicate a significant difference at $p<0.05$.

\subsection{Antioxidant Activity of $A B E$}

As shown in Table $3, \mathrm{ABE}$ had DPPH radical scavenging activity with an $\mathrm{IC}_{50}$ value of $15.84 \pm 0.06 \mu \mathrm{g} / \mathrm{mL}$, whereas the $\mathrm{IC}_{50}$ value of ascorbic acid was $11.83 \pm 2.78 \mu \mathrm{g} / \mathrm{mL}$. This finding indicated that $\mathrm{ABE}$ had less potency than ascorbic acid by 1.3-times. In the TEAC assay, the $\mathrm{IC}_{50}$ value of $\mathrm{ABE}$ was 1.3-fold higher than Trolox. In FRAP assay, $\mathrm{ABE}$ and ascorbic acid exhibited the $\mathrm{EC}_{50}$ value of $182.22 \pm 0.64 \mu \mathrm{g} / \mathrm{mL}$ and $79.39 \pm 1.92 \mu \mathrm{g} / \mathrm{mL}$, respectively. The result suggested that $\mathrm{ABE}$ had 2.3-times less potent than ascorbic acid. 
Table 3. The antioxidant capacities of the anthocyanin-rich fraction of Antidesma bunius fruit extract (ABE).

\begin{tabular}{cccc}
\hline Compounds & $\begin{array}{c}\text { DPPH } \\
\text { IC }_{\mathbf{5 0}} \text { Value }(\mu \mathrm{g} / \mathrm{mL})\end{array}$ & $\begin{array}{c}\text { TEAC } \\
\text { IC }_{\mathbf{5 0}} \text { Value }(\mu \mathrm{g} / \mathbf{m L})\end{array}$ & $\begin{array}{c}\text { FRAP } \\
\text { EC }_{\mathbf{5 0}} \text { Value }(\boldsymbol{\mu g} / \mathbf{m L})\end{array}$ \\
\hline ABE & $15.84 \pm 0.06$ & $166.10 \pm 2.40$ & $182.22 \pm 0.64$ \\
Ascorbic acid & $11.83 \pm 2.78$ & - & $79.39 \pm 1.92$ \\
Trolox & - & $215.36 \pm 0.13$ & - \\
\hline
\end{tabular}

DPPH: 2,2-diphenyl-1-picrylhydrazyl; TEAC: Trolox equivalent antioxidant capacity; FRAP: ferric reducing antioxidant power; $\mathrm{IC}_{50}$ : Half-maximal inhibitory concentration; $\mathrm{EC}_{50}$ : Half-maximal effective concentration.

\section{Discussion}

Phytochemicals, especially anthocyanins, have been interesting to prevent or delay the progression of diabetes and its complications [36]. A meta-analysis of prospective cohort studies described that dietary anthocyanins and berry fruits had been associated with the reduced risk of type 2 diabetes risk [37]. One of the well-established antidiabetic mechanisms of anthocyanin-rich berries is the inhibition of pancreatic $\alpha$-amylase, intestinal $\alpha$-glucosidase, and glucose absorption [36-39]. The present findings exhibit the inhibitory activity of $\mathrm{ABE}$ against intestinal $\alpha$-glucosidase, including maltase and sucrase in vitro. In addition, cyanidin-3-glucoside (C3G) and delphinidin-3-glucoside (D3G) are the major anthocyanins identified in $\mathrm{ABE}$, which are agreed with a previous report in the methanolic extraction of Antidesma bunius [24]. Previous studies have suggested that anthocyanins could inhibit $\alpha$-glucosidase activity. For example, the freeze-dried black currant extract containing anthocyanins, including $232 \mathrm{mg} / \mathrm{kg} \mathrm{C} 3 \mathrm{G}$ and $392 \mathrm{mg} / \mathrm{kg}$ D3G exhibited yeast $\alpha$-glucosidase inhibition. In contrast, the green currant extract did not show an inhibitory effect on this enzyme [40]. Moreover, the study reported that the individual C3G and D3G at the concentration of $66 \mu \mathrm{g} / \mathrm{mL}$ also inhibited the $\alpha$-glucosidase activity [40]. Additionally, C3G able to inhibit intestinal sucrase activity, and it showed the synergistic effect with acarbose on intestinal maltase and sucrase activities [41]. Similarly, D3G $(100 \mu \mathrm{M})$ exhibited the inhibition of $\alpha$-glucosidase by $44.5 \%$ [42]. Based on a previous study, the delphinidin-3-glucoside showed the most potency of $\alpha$-glucosidase inhibition and was followed by cyanidin-3-glucoside, cyanidin-3-rutinoside, and malvidin-3-glucoside [43]. A previous study reported that anthocyanins could inhibit the intestinal $\alpha$-glucosidase by the competitive inhibition between the glycosyl groups of anthocyanins and the active site of enzymes [44]. The scientific evidence demonstrates that cyanidin and delphinidin's inhibitory effect on intestinal $\alpha$-glucosidase may involve the hydrogen bond between hydroxyl groups of their structure and the polar groups in the active site of the enzyme [41]. There also found that the number of hydroxyl groups in the B-ring of anthocyanins associated with an increase of binding affinity to the enzyme [45]. Moreover, the inhibitory effect of C3G and D3G on $\alpha$-glucosidase also depends on the binding affinity with the enzyme and their chemical structure [43]. According to the molecular docking study, the binding of D3G and $\alpha$-glucosidase depends on the polar interaction, hydrogen bonding, and hydrophobic interaction in the enzyme's catalytic site [42]. It is noteworthy that the molecular docking predicted D3G could bind with amino acid residues (Gly402 and Val380) of $\alpha$-glucosidase through hydrogen bonding. In the meantime, C3G showed the binding affinity with amino residues, including Glu231, Val335, Gly402, and Val380 [43]. Therefore, it is hypothesized that $\mathrm{ABE}$ could inhibit $\alpha$-glucosidase (maltase and sucrase) through the interaction of enzymes resulting from cyanidin-3-glucoside and delphinidin-3-glucoside as a predominant anthocyanin in ABE.

Chronic hyperglycemia spontaneously modifies circulating and structural proteins through induction of protein glycation, leading to advanced glycation end productions (AGEs). In general, AGEs can be categorized by their chemical structures into two main groups: fluorescent and cross-link AGEs (e.g., pentosidine, crossline, and methyl glyoxal-lysine dimer or MOLD) and non-fluorescent and non-crosslink AGEs (e.g., $\mathrm{N}^{\varepsilon}$ - 
(carboxymethyllysine) or CML, $\mathrm{N}^{\varepsilon}$-(carboxyethyllysine) or CEL, and pyrraline) [46]. In the present study, fructose has a higher protein glycation rate than glucose because ketose sugar has more reactive than aldose sugar [47,48]. Moreover, fructose has a more open-chain structure than glucose, resulting in a higher reactivity than glucose [49]. ABE $(0.25 \mathrm{mg} / \mathrm{mL})$ decreased the formation of fluorescent AGEs and the level of $\mathrm{N}^{\varepsilon}$-CML in fructose and glucose-glycated BSA throughout the study period. Furthermore, ABE $(0.25 \mathrm{mg} / \mathrm{mL})$ exhibited a similar effect on the reduction of AGE formation as aminoguanidine $(0.25 \mathrm{mg} / \mathrm{mL})$ in the fructose system. According to a previous study, C3G prevented the lysine and arginine residues of the protein, leading to reduced fructosamine formation and BSA glycation [50]. Interestingly, the molecular docking indicated that C3G exhibited BSA glycation's competitive inhibition through the hydrogen bonding with Glu186, Arg427, Ser428, Lys431, Arg435, and Arg458. Moreover, C3G also reduced the BSA glycation by hydrophobic interaction with Leu189 and Ile455 [50].

During the protein glycation, the monosaccharide-mediated BSA glycation induced the change of helical structure of BSA to the $\beta$-sheet structure, resulting in the formation of insoluble proteins, known as amyloids [50,51]. The previous study has reported that the protein glycation decreased the secondary $\alpha$-helix structure of BSA and increased the $\beta$-sheet structure formation [52]. The formation of the cross- $\beta$ structure may involve two pathways, including (i) the covalent bonding between carbohydrate and amino acid residues (Lys and Arg) leading to unfolding protein, (ii) the intramolecular or intermolecular AGE-crosslinks resulting in the local or global unfolding of protein [53]. Consequently, the unfold polypeptides rearrange to form the amyloid fibrils [53]. Our findings demonstrated that fructose-induced the formation of the $\beta$-amyloid cross structure higher than glucose, whereas ABE could reduce the $\beta$-amyloid cross structure level. A previous study revealed that $\mathrm{C} 3 \mathrm{G}$ could decrease amyloid fibril level during the protein glycation [50]. According to the molecular docking study, C3G entered the hydrophobic cavity in the subdomain IIA of BSA. Moreover, C3G interacted with BSA through Van der Waals forces and hydrogen bonding that could prevent BSA's secondary structure [54]. In addition, the inhibitory effect of anthocyanin glycoside on amyloid formation is involved in the interaction between the aromatic ring of anthocyanins [55]. Therefore, it could be hypothesized that ABE may help preserve BSA structure, resulting in reduced fructose- and glucose-induced AGE and $\beta$-amyloid formation. The decreasing of the $\beta$-amyloid cross structure is helpful to prevent or delay the progression of diabetic complications.

The reactive oxygen species (ROS) such as superoxide anion and hydrogen peroxide are generated via the oxidation of Schiff bases or Amadori products during the early stage of the glycation process [56,57]. Moreover, the interaction of AGEs and its receptor also modulates ROS production through the MAPK pathway [58]. The ROS oxidize the thiol group of amino acid cysteine and methionine in protein molecules, resulting in the loss of thiol groups and enzyme inactivity [59,60]. In addition, the oxidation of amino acids (Arg, Lys, and Thr) results in increasing protein carbonyl content [61]. Our findings found that the fructose and glucose-mediated BSA glycation continuously increased protein carbonyl levels throughout the experimental period. Previous studies showed that edible plants containing phenolic compounds reduced the protein oxidation in glycated BSA. For example, Mesona chinesis extract $(0.5-1 \mathrm{mg} / \mathrm{mL})$ decreased the protein carbonyl content in fructose-mediated BSA glycation by $36.2-46.7 \%$ [62]. The flower petal extract of Clitoria ternatea containing anthocyanins and phenolic compounds prevented the formation of protein carbonyl by $8.23-11.34 \%$ at the concentration of $0.25-1 \mathrm{mg} / \mathrm{mL}$ [23]. In the present study, ABE reduced the level of protein carbonyl content in glycated BSA during the four weeks of the experimental period. Several studies support that the free radical scavenging activity of flavonoids may be the mechanism for glycation inhibition and the reduction of protein carbonyl content $[33,34,47]$. Flavonoids could scavenge free radicals produced from the interaction between reducing sugars and protein during the Schiff bases oxidation, leading to blocking the formation of protein glycation and oxidation [20]. 
In the current study, ABE demonstrated antioxidant activity, indicated by DPPH scavenging activity, TEAC, and FRAP. A previous study described that $10 \mu \mathrm{M}$ of C3G or D3G scavenged DPPH radicals with the percentage of inhibition of $32 \%$ and $42 \%$, respectively [63]. The scientific evidence demonstrates that the hydroxylation and methoxylation in the B ring of their structure impact the ability of C3G and D3G for DPPH radicals scavenging. The increased hydroxyl groups in the B ring could increase the radical scavenging activity indicating that delphinidin decreased free radicals greater than cyanidin [64]. Additionally, the highest value of ferric reducing ion power among anthocyanins was found in cyanidin-3-glucoside and delphinidin-3-glucose, following petunidin-3-glucoside, peonidin-3-glucoside, and malvidin-3-glucoside. The reducing capacity is influenced by the pyrogallol or catechol type on B rings of their structure [65]. According to those mentioned above, it is hypothesized that anthocyanins in Antidesma bunius may be responsible for the inhibitory activity against protein glycation and the prevention of oxidative damage to BSA.

\title{
5. Conclusions
}

ABE exhibits antioxidant activity and inhibits carbohydrate digestive enzymes, including intestinal maltase and sucrase. In the glycation model, $\mathrm{ABE}$ also inhibits the reduction of fluorescent AGE formation, $\mathrm{N}^{\varepsilon}$-CML level, protein carbonyl content, and $\beta$-amyloid formation. $\mathrm{ABE}$ may be a promising ingredient that helps suppress carbohydrate digestion and prevent monosaccharide-mediated protein glycation, oxidation, and aggregation.

\begin{abstract}
Author Contributions: Conceptualization, S.N. and S.A.; methodology, P.A., S.N. and S.A.; validation, P.A.; formal analysis, P.A. and S.N.; investigation, P.A., N.C., M.M. and C.C.; data curation, P.A. and S.N.; writing-original draft preparation, P.A.; writing—review and editing, T.T., S.A. and S.N.; visualization, P.A., T.T., K.M. and W.D.; supervision, S.N. All authors have read and agreed to the published version of the manuscript.
\end{abstract}

Funding: This research was funded by the National Research Council of Thailand Fund (NRCT2561002) and the 90th Anniversary Chulalongkorn University, Ratchadaphiseksomphot Endowment Fund, Chulalongkorn University (GCUGR1125602055D).

Institutional Review Board Statement: Not applicable.

Informed Consent Statement: Not applicable.

Data Availability Statement: Data is contained within the article.

Acknowledgments: We would like to thank the 100th Anniversary of Chulalongkorn University Fund for the Doctoral Scholarship.

Conflicts of Interest: The authors declare no conflict of interest.

\section{References}

1. Sarkar, D.; Orwat, J.; Hurburt, T.; Woods, F.; Pitts, J.A.; Shetty, K. Evaluation of phenolic bioactive-linked functionality of blackberry cultivars targeting dietary management of early stages type-2 diabetes using in vitro models. Sci. Hortic. 2016, 212, 193-202. [CrossRef]

2. Spínola, V.; Pinto, J.; Castilho, P.C. Hypoglycemic, anti-glycation and antioxidant in vitro properties of two Vaccinium species from Macaronesia: A relation to their phenolic composition. J. Func. Foods. 2018, 40, 595-605. [CrossRef]

3. Sheard, N.F.; Clark, N.G.; Brand-Miller, J.C.; Franz, M.J.; Pi-Sunyer, F.X.; Mayer-Davis, E.; Kulkarni, K.; Geil, P. Dietary carbohydrate (amount and type) in the prevention and management of diabetes. Diabetes Care 2004, 27, 2266-2271. [CrossRef] [PubMed]

4. Aisa, H.A.; Gao, Y.; Yili, A.; Ma, Q.; Cheng, Z. Beneficial role of chickpea (Cicer arietinum L.) functional factors in the intervention of metabolic syndrome and diabetes mellitus. In Bioactive Food as Dietary Interventions for Diabetes, 2nd ed.; Watson, R.R., Preedy, V.R., Eds.; Academic Press: Oxford, UK, 2019; pp. 615-627.

5. Wolever, T.M.; Mehling, C. Long-term effect of varying the source or amount of dietary carbohydrate on postprandial plasma glucose, insulin, triacylglycerol, and free fatty acid concentrations in subjects with impaired glucose tolerance. Am. J. Clin. Nutr. 2003, 77, 612-621. [CrossRef] [PubMed] 
6. Shannon, C.; Merovci, A.; Xiong, J.; Tripathy, D.; Lorenzo, F.; McClain, D.; Abdul-Ghani, M.; Norton, L.; DeFronzo, R.A. Effect of chronic hyperglycemia on glucose metabolism in subjects with normal glucose tolerance. Diabetes 2018, 67, 2507-2517. [CrossRef] [PubMed]

7. Edirisinghe, I.; Burton-Freeman, B. Anti-diabetic actions of berry polyphenols-Review on proposed mechanisms of action. $J$. Berry Res. 2016, 6, 237-250. [CrossRef]

8. Rossi, E.J.; Sim, L.; Kuntz, D.A.; Hahn, D.; Johnston, B.D.; Ghavami, A.; Szczepina, M.G.; Kumar, N.S.; Sterchi, E.E.; Nichols, B.L.; et al. Inhibition of recombinant human maltase glucoamylase by salacinol and derivatives. FEBS. J. 2006, 273, 2673-2683. [CrossRef] [PubMed]

9. Singh, R.; Barden, A.; Mori, T.; Beilin, L. Advanced glycation endproducts: A review. Diabetologia 2001, 44, 129-146. [CrossRef]

10. Adisakwattana, S.; Sompong, W.; Meeprom, A.; Ngamukote, S.; Yibchok-anun, S. Cinnamic acid and its derivatives inhibit fructose-mediated protein glycation. Int. J. Mol. Sci. 2012, 13, 1778-1789. [CrossRef]

11. Yamagishi, S. Role of advanced glycation end products (AGEs) and receptor for AGEs (RAGE) in vascular damage in diabetes. Exp. Gerontol. 2011, 46, 217-224. [CrossRef]

12. Van de Laar, F.A.; Lucassen, P.L.; Akkermans, R.P.; Van de Lisdonk, E.H.; Rutten, G.E.; Van Weel, C. Alpha-glucosidase inhibitors for patients with type 2 diabetes: Results from a Cochrane systematic review and meta-analysis. Diabetes Care 2005, 28, 154-163. [CrossRef] [PubMed]

13. Scott, L.; Spencer, C. Miglitol: A review of its therapeutic potential in type 2 diabetes mellitus. Drugs 2000, 59, 521-549. [CrossRef] [PubMed]

14. Adisakwattana, S.; Ruengsamran, T.; Kampa, P.; Sompong, W. In vitro inhibitory effects of plant-based foods and their combinations on intestinal $\alpha$-glucosidase and pancreatic $\alpha$-amylase. BMC Complement. Altern. Med. 2012, 12, 110. [CrossRef] [PubMed]

15. Thornalley, P.J. Use of aminoguanidine (Pimagedine) to prevent the formation of advanced glycation endproducts. Arch. Biochem. Biophys. 2003, 419, 31-40. [CrossRef] [PubMed]

16. Friedman, E.A. Evolving pandemic diabetic nephropathy. Rambam Maimonides Med. J. 2010, 1, e0005. [CrossRef]

17. Anhê, F.F.; Desjardins, Y.; Pilon, G.; Dudonné, S.; Genovese, M.I.; Lajolo, F.M.; Marette, A. Polyphenols and type 2 diabetes: A prospective review. PharmaNutrition 2013, 1, 105-114. [CrossRef]

18. Gowd, V.; Jia, Z.; Chen, W. Anthocyanins as promising molecules and dietary bioactive components against diabetes-A review of recent advances. Trends. Food Sci. Technol. 2017, 68, 1-13. [CrossRef]

19. Khoo, H.E.; Azlan, A.; Tang, S.T.; Lim, S.M. Anthocyanidins and anthocyanins: Colored pigments as food, pharmaceutical ingredients, and the potential health benefits. Food Nutr. Res. 2017, 61, 1361779. [CrossRef]

20. Spínola, V.; Pinto, J.; Llorent-Martínez, E.J.; Tomás, H.; Castilho, P.C. Evaluation of Rubus grandifolius L. (wild blackberries) activities targeting management of type-2 diabetes and obesity using in vitro models. Food Chem. Toxicol. 2019, 123, 443-452. [CrossRef]

21. Spínola, V.; Llorent-Martínez, E.J.; Castilho, P.C. Polyphenols of Myrica faya inhibit key enzymes linked to type II diabetes and obesity and formation of advanced glycation endproducts (in vitro): Potential role in the prevention of diabetic complications. Food Res. Int. 2019, 116, 1229-1238. [CrossRef]

22. Ma, H.; Johnson, S.L.; Liu, W.; DaSilva, N.A.; Meschwitz, S.; Dain, J.A.; Seeram, N.P. Evaluation of polyphenol anthocyaninenriched extracts of blackberry, black raspberry, blueberry, cranberry, red raspberry, and strawberry for free radical scavenging, reactive carbonyl species trapping, anti-glycation, anti- $\beta$-amyloid aggregation, and microglial neuroprotective effects. Int. J. Mol. Sci. 2018, 19, 461.

23. Chayaratanasin, P.; Barbieri, M.A.; Suanpairintr, N.; Adisakwattana, S. Inhibitory effect of Clitoria ternatea flower petal extract on fructose-induced protein glycation and oxidation-dependent damages to albumin in vitro. BMC Complement. Altern. Med. 2015, 15, 27. [CrossRef] [PubMed]

24. Jorjong, S.; Butkhup, L.; Samappito, S. Phytochemicals and antioxidant capacities of Mao-Luang (Antidesma bunius L.) cultivars from Northeastern Thailand. Food Chem. 2015, 181, 248-255. [CrossRef] [PubMed]

25. Kukongviriyapan, U.; Kukongviriyapan, V.; Pannangpetch, P.; Donpunha, W.; Sripui, J.; Sae-Eaw, A.; Boonla, O. Mamao Pomace Extract Alleviates Hypertension and Oxidative Stress in Nitric Oxide Deficient Rats. Nutrients 2015, 7, 6179-6194. [CrossRef]

26. Ngamlerst, C.; Udomkasemsab, A.; Kongkachuichai, R.; Kwanbunjan, K.; Chupeerach, C.; Prangthip, P. The potential of antioxidant-rich Maoberry (Antidesma bunius) extract on fat metabolism in liver tissues of rats fed a high-fat diet. BMC Complement. Altern. Med. 2019, 19, 294. [CrossRef]

27. Udomkasemsab, A.; Ngamlerst, C.; Kwanbunjun, K.; Krasae, T.; Amnuaysookkasem, K.; Chunthanom, P.; Prangthip, P. Maoberry (Antidesma bunius) improves glucose metabolism, triglyceride levels, and splenic lesions in high-fat diet-induced hypercholesterolemic rats. J. Med. Food. 2019, 22, 29-37. [CrossRef]

28. Grussu, D.; Stewart, D.; McDougall, G.J. Berry polyphenols inhibit $\alpha$-amylase in vitro: Identifying active components in rowanberry and raspberry. J. Agric. Food Chem. 2011, 59, 2324-2331. [CrossRef]

29. Lee, J.; Durst, R.; Wrolstad, R. Determination of total monomeric antocyanin pigment content of fruit juices, beverages, natural colorants, and wined by the $\mathrm{pH}$ differential method: Collaborative study. J. AOAC Int. 2005, 88, 1269-1278. [CrossRef] 
30. Jiménez-Aspee, F.; Theoduloz, C.; Vieira, M.N.; Rodríguez-Werner, M.A.; Schmalfuss, E.; Winterhalter, P.; Schmeda-Hirschmann, G. Phenolics from the Patagonian currants Ribes spp.: Isolation, characterization and cytoprotective effect in human AGS cells. J. Funct. Foods. 2016, 26, 11-26. [CrossRef]

31. Huang, Z.; Wang, B.; Williams, P.; Pace, R.D. Identification of anthocyanins in muscadine grapes with HPLC-ESI-MS. LWT Food Sci. Technol. 2009, 42, 819-824. [CrossRef]

32. Ramirez, J.E.; Zambrano, R.; Sepúlveda, B.; Kennelly, E.J.; Simirgiotis, M.J. Anthocyanins and antioxidant capacities of six Chilean berries by HPLC-HR-ESI-ToF-MS. Food Chem. 2015, 176, 106-114. [CrossRef] [PubMed]

33. Thilavech, T.; Ngamukote, S.; Abeywardena, M.; Adisakwattana, S. Protective effects of cyanidin-3-rutinoside against monosaccharides-induced protein glycation and oxidation. Int. J. Biol. Macromol. 2015, 75, 515-520. [CrossRef] [PubMed]

34. Jariyapamornkoon, N.; Yibchok-anun, S.; Adisakwattana, S. Inhibition of advanced glycation end products by red grape skin extract and its antioxidant activity. BMC Complement. Altern. Med. 2013, 13, 171. [CrossRef] [PubMed]

35. Suantawee, T.; Wesarachanon, K.; Anantsuphasak, K.; Daenphetploy, T.; Thien-Ngern, S.; Thilavech, T.; Pasukamonset, P.; Ngamukote, S.; Adisakwattana, S. Protein glycation inhibitory activity and antioxidant capacity of clove extract. J. Food Sci. Technol. 2015, 52, 3843-3850. [CrossRef] [PubMed]

36. Castro-Acosta, M.L.; Smith, L.; Miller, R.J.; McCarthy, D.I.; Farrimond, J.A.; Hall, W.L. Drinks containing anthocyanin-rich blackcurrant extract decrease postprandial blood glucose, insulin and incretin concentrations. J. Nutr. Biochem. 2016, 38, 154-161. [CrossRef] [PubMed]

37. Guo, X.; Yang, B.; Tan, J.; Jiang, J.; Li, D. Associations of dietary intakes of anthocyanins and berry fruits with risk of type 2 diabetes mellitus: A systematic review and meta-analysis of prospective cohort studies. Eur. J. Clin. Nutr. 2016, 70, 1360-1367. [CrossRef]

38. Bell, L.; Lamport, D.J.; Butler, L.T.; Williams, C.M. A study of glycaemic effects following acute anthocyanin-rich blueberry supplementation in healthy young adults. Food Funct. 2017, 8, 3104-3110. [CrossRef]

39. Törrönen, R.; McDougall, G.J.; Dobson, G.; Stewart, D.; Hellström, J.; Mattila, P.; Pihlava, J.M.; Koskela, A.; Karjalainen, R. Fortification of blackcurrant juice with crowberry: Impact on polyphenol composition, urinary phenolic metabolites, and postprandial glycemic response in healthy subjects. J. Funct. Foods. 2012, 4, 746-756. [CrossRef]

40. Barik, S.K.; Russell, W.R.; Moar, K.M.; Cruickshank, M.; Scobbie, L.; Duncan, G.; Hoggard, N. The anthocyanins in black currants regulate postprandial hyperglycaemia primarily by inhibiting $\alpha$-glucosidase while other phenolics modulate salivary $\alpha$-amylase, glucose uptake and sugar transporters. J. Nutr. Biochem. 2020, 78, 108325. [CrossRef]

41. Akkarachiyasit, S.; Charoenlertkul, P.; Yibchok-Anun, S.; Adisakwattana, S. Inhibitory activities of cyanidin and its glycosides and synergistic effect with acarbose against intestinal $\alpha$-glucosidase and pancreatic $\alpha$-amylase. Int. J. Mol. Sci. 2010, 11, 3387-3396. [CrossRef]

42. Mojica, L.; Berhow, M.; Gonzalez de Mejia, E. Black bean anthocyanin-rich extracts as food colorants: Physicochemical stability and antidiabetes potential. Food Chem. 2017, 229, 628-639. [CrossRef] [PubMed]

43. Hui, X.; Wu, G.; Han, D.; Stipkovits, L.; Wu, X.; Tang, S.; Brennan, M.A.; Brennan, C.S. The effects of bioactive compounds from blueberry and blackcurrant powders on the inhibitory activities of oat bran pastes against $\alpha$-amylase and $\alpha$-glucosidase linked to type 2 diabetes. Food Res. Int. 2020, 138, 109756. [CrossRef] [PubMed]

44. Boath, A.S.; Stewart, D.; McDougall, G.J. Berry components inhibit $\alpha$-glucosidase in vitro: Synergies between acarbose and polyphenols from black currant and rowanberry. Food Chem. 2012, 135, 929-936. [CrossRef] [PubMed]

45. Zhang, J.; Sun, L.; Dong, Y.; Fang, Z.; Nisar, T.; Zhao, T.; Wang, Z.C.; Guo, Y. Chemical compositions and $\alpha$-glucosidase inhibitory effects of anthocyanidins from blueberry, blackcurrant and blue honeysuckle fruits. Food Chem. 2019, 299, 125102. [CrossRef] [PubMed]

46. Wu, C.H.; Huang, S.M.; Lin, J.A.; Yen, G.C. Inhibition of advanced glycation endproduct formation by foodstuffs. Food Funct. 2011, 2, 224-234. [CrossRef] [PubMed]

47. Ramkissoon, J.S.; Mahomoodally, M.F.; Subratty, A.H.; Ahmed, N. Inhibition of glucose- and fructose-mediated protein glycation by infusions and ethanolic extracts of ten culinary herbs and spices. Asian Paci. J. Trop. Biomed. 2016, 6, 492-500. [CrossRef]

48. Sompong, W.; Meeprom, A.; Cheng, H.; Adisakwattana, S. A comparative study of ferulic acid on different monosaccharidemediated protein glycation and oxidative damage in bovine serum albumin. Molecules 2013, 18, 13886-13903. [CrossRef]

49. Bunn, H.F.; Higgins, P.J. Reaction of monosaccharides with proteins: Possible evolutionary significance. Science 1981, 213, $222-224$. [CrossRef]

50. Prasanna, G.; Jing, P. Cyanidin-3-O-glucoside functions like chemical chaperone and attenuates the glycation mediated amyloid formation in albumin. Arch. Biochem. Biophys. 2018, 643, 50-56. [CrossRef]

51. Wei, Y.; Chen, L.; Chen, J.; Ge, L.; He, R.Q. Rapid glycation with D-ribose induces globular amyloid-like aggregations of BSA with high cytotoxicity to SH-SY5Y cells. BMC Cell Biol. 2009, 10, 10. [CrossRef]

52. Joglekar, M.M.; Panaskar, S.N.; Chougale, A.D.; Kulkarni, M.J.; Arvindekar, A.U. A novel mechanism for antiglycative action of limonene through stabilization of protein conformation. Mol. Biosyst. 2013, 9, 2463-2472. [CrossRef] [PubMed]

53. Bouma, B.; Kroon-Batenburg, L.M.; Wu, Y.P.; Brünjes, B.; Posthuma, G.; Kranenburg, O.; De Groot, P.G.; Voest, E.E.; Gebbink, M.F. Glycation induces formation of amyloid cross-beta structure in albumin. J. Biol. Chem. 2003, 278, 41810-41819. [CrossRef] [PubMed] 
54. Shi, J.-H.; Wang, J.; Zhu, Y.-Y.; Chen, J. Characterization of intermolecular interaction between cyanidin-3-glucoside and bovine serum albumin: Spectroscopic and molecular docking methods. Luminescence 2014, 29, 522-530. [CrossRef] [PubMed]

55. Rivière, C.; Richard, T.; Vitrac, X.; Mérillon, J.-M.; Valls, J.; Monti, J.-P. New polyphenols active on $\beta$-amyloid aggregation. Bioorg. Med. Chem. Lett. 2008, 18, 828-831. [CrossRef] [PubMed]

56. Mossine, V.V.; Linetsky, M.; Glinsky, G.V.; Ortwerth, B.J.; Feather, M.S. Superoxide free radical generation by Amadori compounds: The role of acyclic forms and metal ions. Chem. Res. Toxicol. 1999, 12, 230-236. [CrossRef] [PubMed]

57. Smith, P.R.; Thornalley, P.J. Mechanism of the degradation of non-enzymatically glycated proteins under physiological conditions. Eur. J. Biochem. 1992, 210, 729-739. [CrossRef]

58. Vlassara, H.; Striker, G.E. Advanced glycation endproducts in diabetes and diabetic complications. Endocrin. Metab. Clin. 2013, 42, 697-719. [CrossRef]

59. Acimovic, J.; Stanimirović, B.; Mandic, L. The role of the thiol group in protein modification with methylglyoxal. J. Serb. Chem. Soc. 2009, 74, 867-883. [CrossRef]

60. Zeng, J.; Davies, M.J. Protein and low molecular mass thiols as targets and inhibitors of glycation reactions. Chem. Res. Toxicol. 2006, 19, 1668-1676. [CrossRef]

61. Dalle-Donne, I.; Rossi, R.; Giustarini, D.; Milzani, A.; Colombo, R. Protein carbonyl groups as biomarkers of oxidative stress. Clin. Chim. Acta 2003, 329, 23-38. [CrossRef]

62. Adisakwattana, S.; Thilavech, T.; Chusak, C. Mesona Chinensis Benth extract prevents AGE formation and protein oxidation against fructose-induced protein glycation in vitro. BMC Complement. Altern. Med. 2014, 14, 130. [CrossRef] [PubMed]

63. Kähkönen, M.P.; Heinonen, M. Antioxidant activity of anthocyanins and their aglycones. J. Agric. Food Chem. 2003, 51, 628-633. [CrossRef] [PubMed]

64. Rice-Evans, C.A.; Miller, N.J.; Paganga, G. Structure-antioxidant activity relationships of flavonoids and phenolic acids. Free Radic. Biol. Med. 1996, 20, 933-956. [CrossRef]

65. Jordheim, M.; Aaby, K.; Fossen, T.; Skrede, G.; Andersen, Ø.M. Molar absorptivities and reducing capacity of pyranoanthocyanins and other anthocyanins. J. Agric. Food Chem. 2007, 55, 1. [CrossRef] [PubMed] 